\title{
New generation biofuel: continuous acidogenesis of sucrose-raffinose mixture simulating vinasse is promoted by $\gamma$-alumina pellets
}

\author{
Katerina Lappa ${ }^{1}$, Panagiotis Kandylis' ${ }^{1}$, Nikolaos Bastas², Stavros Klaoudatos², Nikolaos Athanasopoulos ${ }^{3}$,
} Argyro Bekatorou ${ }^{1}$, Maria Kanellaki ${ }^{1}$ and Athanasios A Koutinas ${ }^{1 *}$

\begin{abstract}
Background: This investigation comprises a contribution on the production of a new generation biofuel using the industrial liquid waste of bioethanol distilleries, known as vinasse. This study focuses on the exploitation of vinasse as an acidogenesis substrate for volatile fatty acids and simultaneous ethanol production. These products can be used for ester production, which is the new generation biofuel. Therefore, the aims of the present study are (i) to examine any promotional effect of $\gamma$-alumina on acidogenesis of a sucrose-raffinose mixture simulating vinasse, (ii) to study the operational stability of the continuous acidogenesis of sucrose and raffinose and subsequently of vinasse, and (iii) to determine the volatile fatty acid chemical composition and ethanol formation.

Results: Batch acidogenesis of sucrose and raffinose mixtures showed that $y$-alumina promoted fermentation leading to an increase in the volatile fatty acid yield factor from $40 \%$ to $95 \%$ compared to free cells. The application of the system in continuous mode for more than 3 months showed that the continuous volatile fatty acid productivity obtained was higher than $7 \mathrm{~g} / \mathrm{L} /$ day. Lactic acid was the predominant acid when sucrose and raffinose were used while butyric acid in the case of vinasse. The highest volatile fatty acid concentration reached was $19 \mathrm{~g} / \mathrm{L}$ for vinasse.

Conclusions: A promoting effect of $\gamma$-alumina in acidogenic fermentation of sucrose-raffinose and vinasse is reported. Continuous acidogenesis of sucrose-raffinose mixtures and vinasse using $y$-alumina with immobilized cells showed high operational stability (more than 3 months). These findings result in easy scale up of the process that will produce a high annual added value of $\$ 11,000,000$ in a daily bioethanol production plant of 50,000 L.
\end{abstract}

Keywords: $\gamma$-Alumina, Acidogenic fermentation, Butyric acid, Lactic acid, Ethanol, Volatile fatty acids, Vinasse, Raffinose

\section{Background}

In the European Union, about $29 \%$ of the total ethanol produced comes from industries using molasses [1]. After ethanol recovery, a liquid residue known as vinasse is produced ( 9 to $14 \mathrm{~L}$ per liter of ethanol) with a very high organic load $[2,3]$. The treatment and disposal of vinasse are very important since it may cause serious environmental problems due to its high chemical oxygen demand (COD).

Several methods have been proposed for the treatment of vinasse prior its disposal. Among them, fertirrigation

\footnotetext{
*Correspondence: a.a.koutinas@upatras.gr

${ }^{1}$ Food Biotechnology Group, Department of Chemistry, University of Patras, 26500 Patra, Greece

Full list of author information is available at the end of the article
}

(fertilization and irrigation) is the method with most applications [4], but several problems related to soil and groundwater contamination have been reported $[5,6]$. Other methods of vinasse disposal, but too expensive, are vinasse recirculation and vinasse concentration for volume reduction [7].

A biorefinery concept for vinasse exploitation includes its use as a substrate for fermentation and the production of value-added co-products, such as volatile fatty acids and ethanol, for application in novel biofuel production. This approach could reduce the problem of vinasse disposal and enhance the sustainability of sugarcane-toethanol plants. The use of volatile fatty acids and ethanol for the production of esters is very promising as a novel biofuel. In the frame of this possibility, it was reported that 
in the acidogenesis of glucose in a batch mode using anaerobic mixed culture, volatile fatty acids and ethanol were formed [8]. This gives the possibility for simultaneous production of the two chemicals that are necessary for the esterification reaction. The use of such esters in a homogeneous charge compression ignition engine gave promising results for use of such alternative liquid biofuels produced by anaerobic treatment of waste materials [9]. Furthermore, the porous $\gamma$-alumina was found to be an effective support for cell immobilization [10] and promoter of methane [11] and alcoholic [12] fermentations. Based on these properties of $\gamma$-alumina, it was recently found that this material promoted anaerobic acidogenic fermentation of glucose as a model compound both in batch and continuous modes, leading to accumulation of mainly volatile fatty acids (VFAs) and ethanol $[13,14]$.

Therefore, the aims of the present study are (i) to examine any promotional effect of $\gamma$-alumina on the acidogenesis of a sucrose-raffinose mixture simulating vinasse, the liquid waste of alcohol distillery; (ii) to study the operational stability of the continuous acidogenesis of sucrose and raffinose and subsequently of vinasse; and (iii) to determine the VFA chemical composition and ethanol formation.

\section{Results and discussion}

\section{Rationale of the investigation}

The last decades, research efforts have been started, aiming to produce a new generation biofuel based on ester production from organic acids of the acidogenic fermentation using anaerobic mixed culture in the fermentation of glucose, resulting also in the simultaneous production of ethanol [8]. Furthermore, we discovered the promotional effect of $\gamma$-alumina in the acidogenesis of glucose [13] and under conditions favoring butyric acid production in the same fermentation of glucose medium [14]. These works open the way for the production of the new generation biofuel from wastes of the food production industry. Vinasse, the liquid waste of ethanol distilleries with high production capacity, contains sucrose and raffinose as residual sugar. Therefore, a study of acidogenesis of a model mixture of sucrose and raffinose is necessary to be carried out, as a precursor of vinasse treatment. This investigation's objectives are to show any promotional effect by $\gamma$-alumina, as compared with free cells in the acidogenesis of sucrose and raffinose mixtures; to examine the chemical composition of VFA and ethanol formation in continuous processing; and to study the effectiveness of a $\gamma$-alumina-supported biocatalyst in the continuous acidogenesis of vinasse after adaptation of biocatalyst in a synthetic medium containing sucrose and raffinose found in sugarcane and sugar-beet vinasse. To achieve the objectives, batch and continuous acidogenic fermentations were performed and samples were analyzed for ethanol, acetic acid, propionic acid, butyric acid, lactic acid, succinic acid, malic acid, and valeric acid.

\section{Effect of $\gamma$-alumina on VFA and ethanol production using sucrose and raffinose mixtures}

Batch acidogenesis was performed at $37^{\circ} \mathrm{C}$ and a $\mathrm{pH}$ value of 7 as the optimum conditions were obtained. Mixtures of sucrose and raffinose $(20 \mathrm{~g} / \mathrm{L})$ were used in order to simulate vinasse. The residual sugar in vinasse is less than $10 \mathrm{~g} / \mathrm{L}$ containing sucrose and raffinose. However, the total organic material in vinasse is higher due to amino acid content, natural colorings, and so on. This is estimated to be a total organic mass of more than $20 \mathrm{~g} / \mathrm{L}$. Firstly, sucrose was used and then raffinose was added in various concentrations in order to obtain adaption to the sugars before vinasse treatment, which contains these carbohydrates. The simulation of vinasse was attempted with carbohydrates and yeast extract addition which is rich in amino acids. $\gamma$-Alumina increased the VFA yield factor in all mixtures of sucrose and raffinose from $40 \%$ to $95 \%$ as compared with free cells (Figure 1). The lower improvement was for sucrose, while the higher was for raffinose. Table 1 shows results of batch acidogenesis of sucrose and raffinose mixtures using immobilized cells on porous $\gamma$-alumina. VFAs formed in all repeated batch fermentations, proving the suitability of the biocatalyst for continuous mode operation. All sucrose and raffinose have been bioconversed in all batches and all mixtures. The yield factor varies from 0.20 to $0.42 \mathrm{~g} / \mathrm{g}$ using an initial sugar concentration of $20 \mathrm{~g} / \mathrm{L}$. VFA concentration was from 4 to $8.49 \mathrm{~g} / \mathrm{L}$ while ethanol formation did not exceed $1.4 \mathrm{~mL} / \mathrm{L}$. VFAs that were formed were acetic acid, propionic acid, butyric acid, lactic acid, and valeric acid. Lactic acid had a higher concentration in comparison with other acids. These results encouraged the study of continuous acidogenesis by immobilized cells on $\gamma$-alumina in order to achieve the aforementioned objectives.

\section{VFA and ethanol production in continuous acidogenesis of sucrose and raffinose mixtures}

Continuous acidogenesis was performed using successively sucrose, sucrose-raffinose mixtures, and vinasse (Figure 2). Lactic acid was produced at the highest concentration as compared with acetic acid, butyric acid, succinic acid, and malic acid. Lactic acid, in continuous fermentation of sucrose and sucrose-raffinose mixtures, accounts for $65 \%$ of total VFAs while butyric acid was not produced at all. Figure 3 illustrates that the VFA yield factor increased as the time proceeds and as the acidogenesis proceeds from sucrose to sucrose-raffinose mixtures. The ethanol yield factor is reduced as the continuous acidogenesis proceeds. The operational stability 


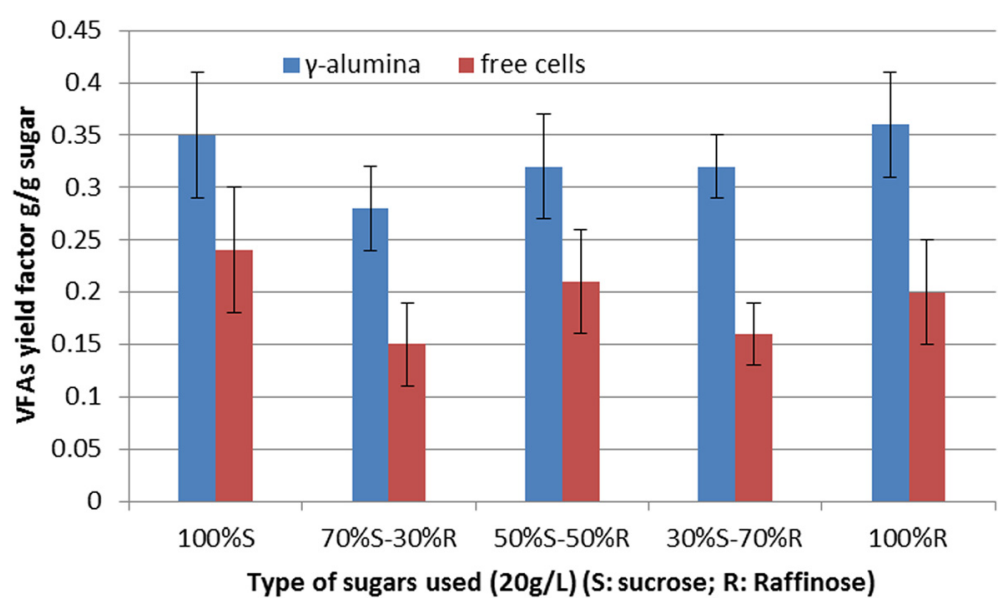

Figure 1 VFA yield factor during batch acidogenesis. Comparison of VFA yield factor during batch acidogenesis using $\gamma$-alumina-supported mixed anaerobic culture versus composition of sugars at $37^{\circ} \mathrm{C}$ and initial pH 7; suc: sucrose, raf: raffinose, vinasse diluted from concentrate, VFAs: volatile fatty acids.

of the continuous mode acidogenesis remains constant and increases for a long period of time as indicated by the stability of VFA productivity in Figure 4. Conversion varies from $34 \%$ up to $78.8 \%$ (Tables 2 and 3). The residual sugar that remains makes it possible for the effluent from the bioreactor to pass through $\gamma$-alumina-supported yeast cells to increase ethanol content which is necessary for the esterification reaction.

\section{VFA production in continuous acidogenesis of alcohol distillery's liquid waste}

After more than 2 months of operation, vinasse was used as influent in the continuous system and the results are summarized in Table 3. Vinasse was prepared from concentrate after dilution. Firstly, a dilution ratio of 1:5 was used simulating the content of fresh vinasse. The use of vinasse caused an increase in the total VFA content with a mean value of $14 \mathrm{~g} / \mathrm{L}$ (varying from 7 to $17 \mathrm{~g} / \mathrm{L}$ ) and changed the VFA composition (Table 3 and Figure 2). More specifically, the concentration of lactic acid decreased to a mean value of $7 \mathrm{~g} / \mathrm{L}$ (accounting for $50 \%$ of total VFA content), and subsequently, butyric acid and succinic acid concentrations increased to $4 \mathrm{~g} / \mathrm{L}$ for each one (accounting for $25 \%$ of total VFAs each). The system continued its operation using 1:5 vinasse for 15 days, and then a more diluted vinasse was used. This time, the dilution ratio was $1: 10$ from the concentrated vinasse which is similar to the 1:2 dilution from fresh vinasse. This led to a further increase in total VFA concentration to a mean value of $16 \mathrm{~g} / \mathrm{L}$ reaching at the last fermentations even up to $19 \mathrm{~g} / \mathrm{L}$. Furthermore, the lactic acid concentration continued to decrease reaching a value of $2 \mathrm{~g} / \mathrm{L}$, and the corresponding mean values for butyric and succinic acids were 7 and $4.5 \mathrm{~g} / \mathrm{L}$, respectively. The percentage of each acid in the total VFA content was $63 \%$ for butyric acid, $26 \%$ for succinic acid, and $10 \%$ for lactic acid. The results of VFA, lactic acid, and butyric acid productivities versus fermentation time are presented in Figure 4, showing the decrease of lactic acid and subsequently increase of butyric acid productivity. The VFA productivity continuously increases, and especially when vinasse is used, it reaches values of more than $7 \mathrm{~g} / \mathrm{L} /$ day.

\section{Scientific and technological consideration}

$\gamma$-Alumina is a porous material with numerous applications in catalysis. Furthermore, it has been used in several fermentation systems such as methane production and alcoholic fermentation and has been proven to be a very promising promoter. Recently, $\gamma$-alumina had promotional effect on acidogenic fermentations of glucose showing improvement of ethanol and VFA production $[13,14]$. The present investigation also proves the promotional effect of $\gamma$-alumina on the acidogenic fermentation of sucrose and raffinose sugars which are contained in sugarcane and sugar-beet vinasse. Sucrose-raffinose mixture was used as a model substrate, simulating vinasse, and $\gamma$-alumina is also used as an immobilization support for the mixed anaerobic culture leading to increased cell densities in the bioreactor facilitating the repeated batch and continuous processing. Repeated batch processing of sucrose-raffinose mixtures shows the suitability of biocatalyst for continuous processing. However, the batch process gave a lower VFA yield factor and VFA concentration as compared with the continuous process, which had an operational stability for a long time. The adaptation of biocatalyst in sucroseraffinose mixtures accommodates a rapid start-up for vinasse acidogenic fermentation. Vinasse treatment leads to an important VFA yield factor, and in the mixtures of VFAs produced, lactic acid and butyric acid predominate. 
Table 1 Batch acidogenesis of sucrose and raffinose mixtures using $\gamma$-alumina-supported anaerobic mixed culture

\begin{tabular}{|c|c|c|c|c|c|c|c|c|c|c|c|c|c|c|}
\hline $\begin{array}{l}\text { Initial sugar } \\
\text { composition }\end{array}$ & $\begin{array}{l}\text { Repeated } \\
\text { batch }\end{array}$ & $\begin{array}{l}\text { Final } \\
\text { pH }\end{array}$ & $\begin{array}{l}\text { Ethanol } \\
(\mathrm{mL} / \mathrm{L})\end{array}$ & $\begin{array}{l}\text { Acetic } \\
\text { acid (g/L) }\end{array}$ & $\begin{array}{l}\text { Propionic } \\
\text { acid (g/L) }\end{array}$ & $\begin{array}{l}\text { Butyric } \\
\text { acid (g/L) }\end{array}$ & $\begin{array}{l}\text { Lactic } \\
\text { acid (g/L) }\end{array}$ & $\begin{array}{l}\text { Succinic } \\
\text { acid }(g / L)\end{array}$ & $\begin{array}{l}\text { Malic } \\
\text { acid (g/L) }\end{array}$ & $\begin{array}{l}\text { Valeric } \\
\text { acid (g/L) }\end{array}$ & $\begin{array}{l}\text { Total } \\
\text { VFAs (g/L) }\end{array}$ & $\begin{array}{l}\text { Residual } \\
\text { sugar (g/L) }\end{array}$ & $\begin{array}{l}\text { Sugar } \\
\text { conversion (\%) }\end{array}$ & $\begin{array}{l}\text { VFA } \\
\text { yield }(g / g)\end{array}$ \\
\hline \multirow[t]{3}{*}{$100 \%$ sucrose } & 1 & 5.6 & 0.55 & 1.21 & 0.29 & 1.31 & 1.23 & - & - & - & 4.04 & 0 & 100 & 0.20 \\
\hline & 2 & 5.1 & 0.44 & 1.73 & 1.15 & 1.29 & 1.88 & - & - & 2.80 & 8.85 & 0 & 100 & 0.44 \\
\hline & 3 & 4.7 & 0.34 & 1.50 & 0.79 & 1.05 & 3.43 & - & - & 1.43 & 8.20 & 0 & 100 & 0.41 \\
\hline \multirow{3}{*}{$\begin{array}{l}70 \% \text { sucrose } \\
30 \% \text { raffinose }\end{array}$} & 1 & 5.6 & 0.74 & 1.44 & 0.69 & 2.56 & 0.63 & - & - & - & 5.32 & 0 & 100 & 0.27 \\
\hline & 2 & 5.2 & 0.40 & 1.73 & 1.24 & 1.96 & 0.70 & - & - & - & 5.63 & 0 & 100 & 0.28 \\
\hline & 3 & 4.9 & 0.20 & 0.99 & 0.64 & 0.94 & 0.81 & - & - & 2.33 & 5.71 & 0 & 100 & 0.29 \\
\hline \multirow{3}{*}{$\begin{array}{l}50 \% \text { sucrose } \\
50 \% \text { raffinose }\end{array}$} & 1 & 5.4 & 1.04 & 1.19 & - & 1.36 & 1.45 & - & - & - & 4.00 & 0 & 100 & 0.20 \\
\hline & 2 & 5.0 & 0.85 & 1.43 & 0.53 & 1.51 & 1.36 & - & - & 2.64 & 7.47 & 0 & 100 & 0.37 \\
\hline & 3 & 4.7 & 0.30 & 1.04 & 0.47 & 1.01 & 3.77 & 0.86 & 0.94 & - & 8.09 & 0 & 100 & 0.40 \\
\hline \multirow{3}{*}{$\begin{array}{l}30 \% \text { sucrose } \\
70 \% \text { raffinose }\end{array}$} & 1 & 5.5 & 0.98 & 1.53 & 0.35 & 1.77 & 1.09 & 0.86 & - & - & 5.60 & 0 & 100 & 0.28 \\
\hline & 2 & 5.1 & 0.47 & 1.49 & 0.58 & 1.87 & 0.98 & - & - & - & 4.92 & 0 & 100 & 0.25 \\
\hline & 3 & 4.8 & 0.29 & 1.39 & 0.68 & 1.55 & 2.36 & - & - & 2.32 & 8.30 & 0 & 100 & 0.42 \\
\hline \multirow[t]{3}{*}{$100 \%$ raffinose } & 1 & 5.2 & 1.4 & 2.63 & 1.55 & 3.20 & 1.11 & - & - & - & 8.49 & 0 & 100 & 0.42 \\
\hline & 2 & 4.9 & 0.6 & 1.11 & 0.51 & 1.34 & 1.36 & - & - & 2.83 & 7.15 & 0 & 100 & 0.36 \\
\hline & 3 & 4.5 & 0.1 & 0.32 & 0.37 & 0.75 & 4.53 & - & - & - & 5.97 & 0 & 100 & 0.30 \\
\hline
\end{tabular}




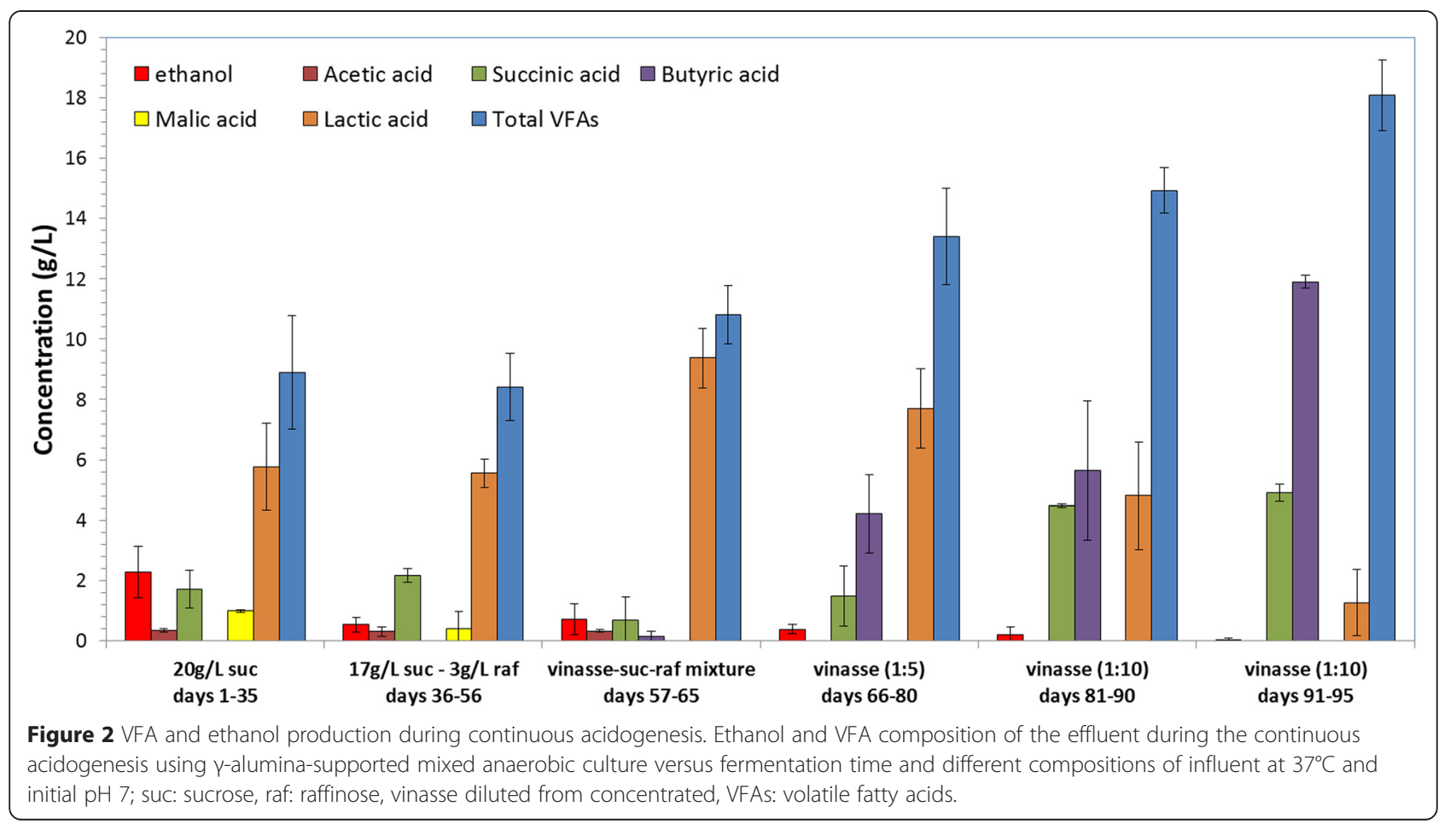

The last is of technological importance due to their esters with ethanol which have increased boiling and ignition points and viscosity, simulating better gasoline and therefore being a more suitable fuel to be added in biodiesel. Moreover, the results clearly showed that lactic acid is the main VFA in the acidogenesis of sucrose, sucroseraffinose mixtures, and sucrose-raffinose-vinasse mixtures, while butyric acid is the main VFA when only vinasse was used. The formation of butyric acid at high concentrations in continuous acidogenesis of vinasse complies with the result of favoring butyric acid formation of a previous study [14]. Ethanol is necessary for the esterification of VFAs and can be produced after mixing of the effluent containing VFAs with a liquid waste containing glucose, sucrose, or lactose and supplying it through a second continuous bioreactor for ethanol formation in the same solution with VFAs. The second bioreactor can contain $\gamma$-alumina-supported yeast [10] or kefir yeast cells [15]. Based on the results of this investigation, one ethanol distillery with 50,000 L daily ethanol production can produce

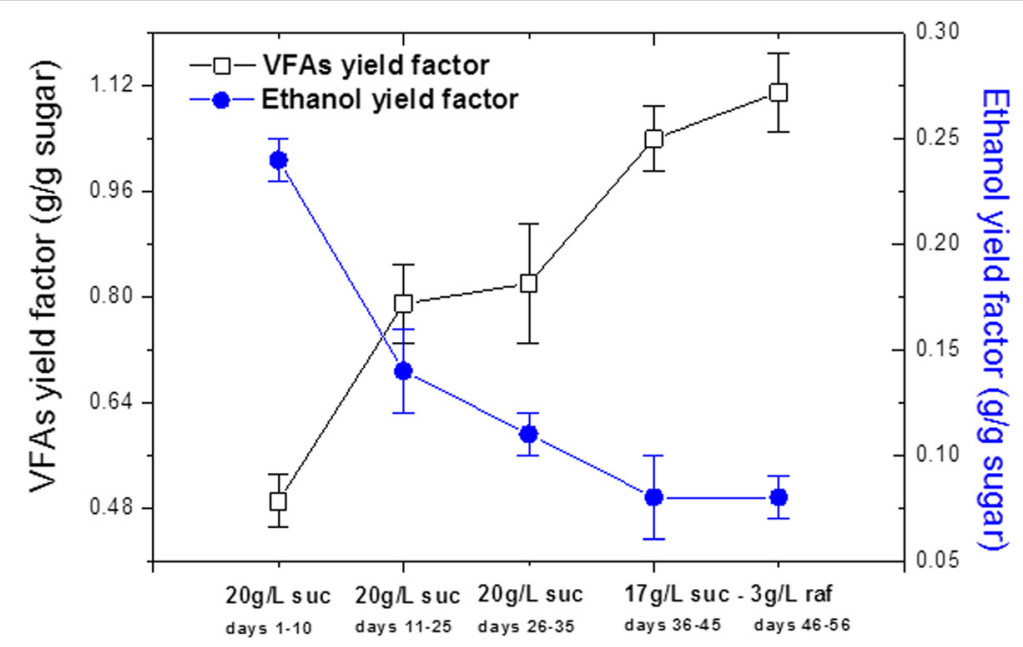

Figure 3 VFA and ethanol yield factor during continuous acidogenesis. Yield factors during the continuous acidogenesis using $\gamma$-alumina-supported mixed anaerobic culture versus fermentation time and different compositions of influent at $37^{\circ} \mathrm{C}$ and initial pH 7 ; suc: sucrose, raf: raffinose, VFAs: volatile fatty acids. 


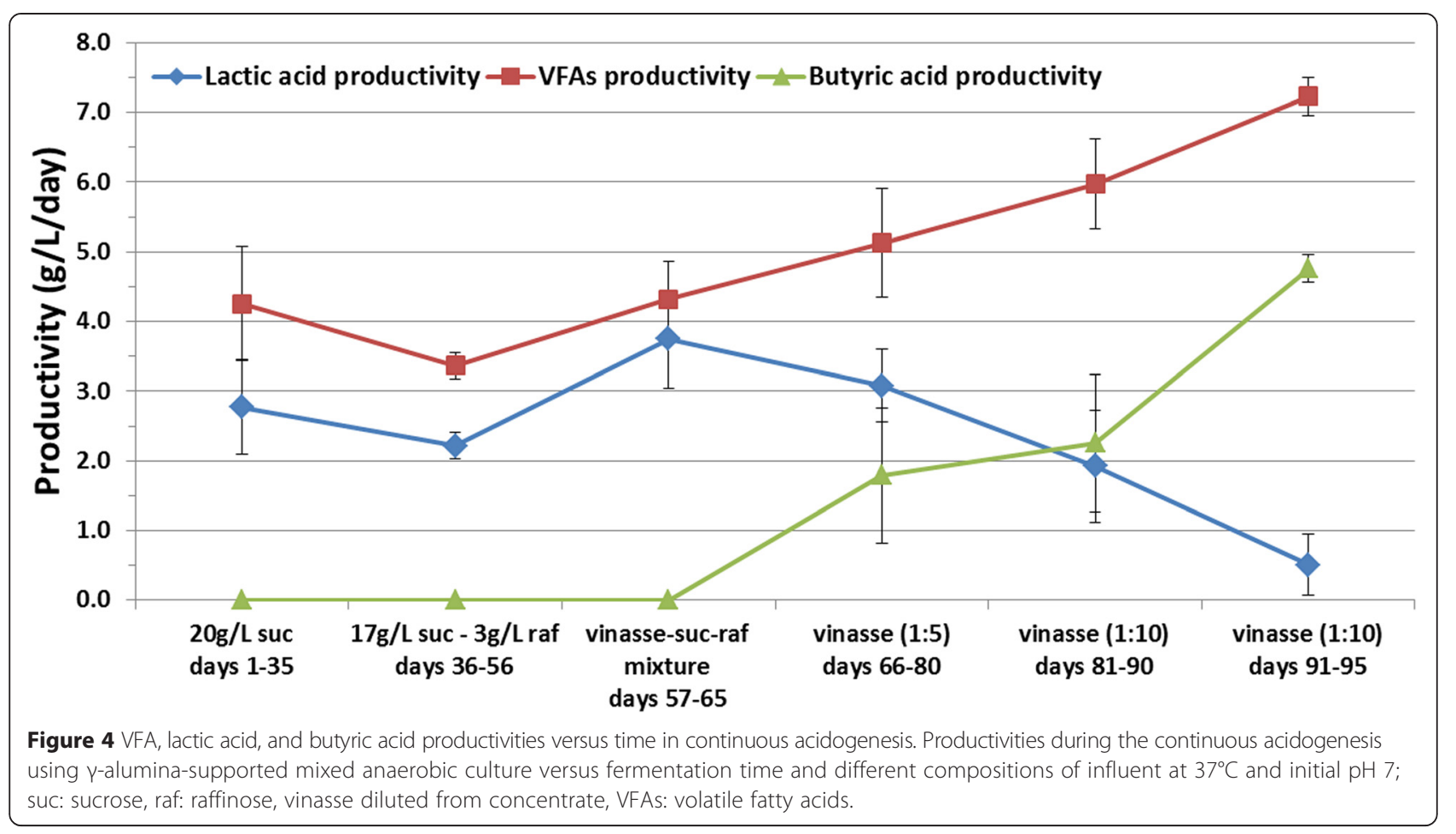

from its liquid waste vinasse a maximum of 15,000 L of esters daily as a new generation biofuel. Therefore, the annual added value is estimated to be $\$ 11,000,000$. More specifically, 50,000 $\mathrm{L}$ of ethanol will produce $575,000 \mathrm{~L}$ of vinasse, which will result, after acidogenesis, to $11,500 \mathrm{~kg}$ of acids daily. After esterification, these acids will result to $15,000 \mathrm{~L}$ of esters per day and therefore 5,475,000 L annually. If this replaces gasoline, it means an added value of almost $\$ 11,000,000$. This added value will reduce bioethanol production cost by about $30 \%$.

\section{Conclusions}

The acidogenic fermentation of sucrose and raffinose is promoted by $\gamma$-alumina. Batch acidogenesis of sucroseraffinose mixtures gave a lower concentration and yield factor of VFAs than the continuous process. Continuous acidogenesis of sucrose-raffinose mixtures using $\gamma$-alumina with immobilized cells has high operational stability, and the adaptation of a biocatalyst results to a rapid scale up for the acidogenesis of vinasse. Lactic acid is the predominant VFA when synthetic medium is used, and butyric acid predominates in VFAs produced when vinasse is used. The added value produced from the new generation biofuel as a bioproduct of an ethanol distillery will reduce its production cost by about $30 \%$.

\section{Materials and methods}

\section{Culture and growth media}

Mixed bacterial anaerobic culture was obtained from an upflow anaerobic sludge blanket (UASB) bioreactor and was inoculated in a medium containing $50 \mathrm{~g} / \mathrm{L}$ glucose, aqueous $\mathrm{NH}_{3}$ and $50 \% \mathrm{H}_{3} \mathrm{PO}_{4}$ (to achieve a COD:N:P ratio of 100:5:1), $\mathrm{NaHCO}_{3} 4 \mathrm{~g} / \mathrm{L}$, and yeast extract $4 \mathrm{~g} / \mathrm{L}$, without $\mathrm{pH}$ adjustment [11]. Cell growth was carried out at $37^{\circ} \mathrm{C}$. The medium was sterilized by autoclaving at $120^{\circ} \mathrm{C}$ for $10 \mathrm{~min}$.

\section{Batch acidogenic fermentation of sucrose and raffinose mixtures}

For the repeated batch fermentations, conical flasks were used containing immobilized mixed anaerobic culture on $100 \mathrm{~g}$ cylindrical $\gamma$-alumina and $100 \mathrm{~mL}$ of synthetic medium containing $20 \mathrm{~g} / \mathrm{L}$ sugars. Fermentations were carried out at $37^{\circ} \mathrm{C}$ with an initial $\mathrm{pH}$ of 7 . Synthetic medium with five different compositions of sugars was used containing $20 \mathrm{~g} / \mathrm{L}$ sucrose, $14 \mathrm{~g} / \mathrm{L}$ sucrose and $6 \mathrm{~g} / \mathrm{L}$ raffinose, $10 \mathrm{~g} / \mathrm{L}$ sucrose and $10 \mathrm{~g} / \mathrm{L}$ raffinose, $6 \mathrm{~g} / \mathrm{L}$ sucrose and $14 \mathrm{~g} / \mathrm{L}$ raffinose, and $20 \mathrm{~g} / \mathrm{L}$ raffinose. Each medium also contained aqueous $\mathrm{NH}_{3}$ and $50 \% \mathrm{H}_{3} \mathrm{PO}_{4}$ (to achieve a COD:N:P ratio of 100:5:1), $\mathrm{NaHCO}_{3} 4 \mathrm{~g} / \mathrm{L}$, and yeast extract $4 \mathrm{~g} / \mathrm{L}$, with $\mathrm{pH}$ adjustment at 7 [11]. The media were sterilized by autoclaving at $120^{\circ} \mathrm{C}$ for $10 \mathrm{~min}$.

\section{Cell immobilization and continuous anaerobic acidogenic} fermentation of sucrose

The mixed culture was fixed on porous cylindrical $\gamma$-alumina pellets $\left(1.40 \mathrm{~m}^{2} / \mathrm{g}\right.$ surface area $)$ to increase rate of fermentation and enable continuous processing. The experimental apparatus used for cell immobilization and for continuous acidogenic fermentation consisted of 
Table 2 Continuous acidogenesis of synthetic media using $\mathrm{\gamma}$-alumina-supported anaerobic mixed culture

\begin{tabular}{|c|c|c|c|}
\hline \multicolumn{4}{|l|}{ Influent } \\
\hline Feed & $\begin{array}{l}\text { Initial } \\
\text { sugar (g/L) }\end{array}$ & $\begin{array}{l}\text { Flow rate } \\
\text { (L/day) }\end{array}$ & $\begin{array}{l}\text { Operat } \\
\text { time }(d\end{array}$ \\
\hline \multirow[t]{31}{*}{ Sucrose } & 20 & 0.2 & 1 \\
\hline & 20 & 0.2 & 2 \\
\hline & 20 & 0.4 & 3 \\
\hline & 20 & 0.4 & 4 \\
\hline & 20 & 0.4 & 6 \\
\hline & 20 & 0.3 & 7 \\
\hline & 20 & 0.3 & 8 \\
\hline & 20 & 0.3 & 9 \\
\hline & 20 & 0.25 & 10 \\
\hline & 20 & 0.25 & 11 \\
\hline & 20 & 0.25 & 12 \\
\hline & 20 & 0.25 & 13 \\
\hline & 20 & 0.25 & 14 \\
\hline & 20 & 0.25 & 15 \\
\hline & 20 & 0.25 & 16 \\
\hline & 20 & 0.25 & 17 \\
\hline & 20 & 0.25 & 18 \\
\hline & 20 & 0.25 & 21 \\
\hline & 20 & 0.2 & 23 \\
\hline & 20 & 0.2 & 24 \\
\hline & 20 & 0.2 & 25 \\
\hline & 20 & 0.2 & 26 \\
\hline & 20 & 0.2 & 27 \\
\hline & 20 & 0.2 & 28 \\
\hline & 20 & 0.2 & 29 \\
\hline & 20 & 0.2 & 31 \\
\hline & 20 & 0.2 & 32 \\
\hline & 20 & 0.2 & 33 \\
\hline & 20 & 0.2 & 34 \\
\hline & 20 & 0.2 & 35 \\
\hline & & 0.2 & 37 \\
\hline
\end{tabular}

$$
\text { Effluent }
$$

\begin{tabular}{llllllll}
\hline pH Ethanol Acetic Lactic & Succinic & Malic & Butyric & Total & Residual Sugar & VFA & VFA productivity
\end{tabular}

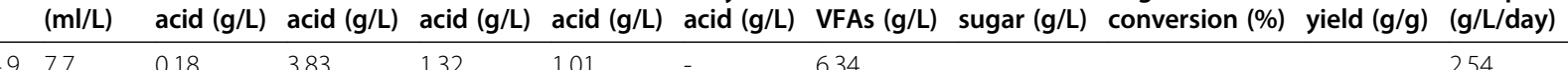

\begin{tabular}{|c|c|c|c|c|c|c|c|c|c|c|c|}
\hline 4.9 & 7.7 & 0.18 & 3.83 & 1.32 & 1.01 & - & 6.34 & & & & 2.54 \\
\hline 4.8 & 8.9 & 0.21 & 4.21 & 1.36 & 1.01 & - & 6.79 & 5.44 & 72.8 & 0.47 & 2.72 \\
\hline 4.7 & 10.5 & 0.23 & 4.41 & 1.34 & 1.08 & - & 7.06 & & & & 5.65 \\
\hline 4.8 & 5.7 & 0.33 & 3.89 & 1.01 & 1.01 & - & 6.24 & & & & 4.99 \\
\hline 4.8 & 2.9 & 0.39 & 3.35 & 0.84 & 1.01 & - & 5.59 & 7.06 & 64.7 & 0.43 & 4.47 \\
\hline 4.7 & 1.1 & 0.38 & 3.32 & 0.91 & 1.00 & - & 5.61 & & & & 3.37 \\
\hline 4.7 & 1.0 & 0.35 & 3.83 & 0.99 & 0.99 & - & 6.16 & & & & 3.70 \\
\hline 4.7 & 1.0 & 0.34 & 4.60 & 1.09 & 0.99 & - & 7.02 & 7.60 & 62.0 & 0.57 & 4.21 \\
\hline 4.7 & 1.94 & 0.32 & 5.35 & 1.17 & 0.97 & - & 7.81 & & & & 3.91 \\
\hline 4.6 & 1.96 & 0.35 & 6.61 & 1.26 & 0.97 & - & 9.18 & & & & 4.59 \\
\hline 4.5 & 1.85 & 0.32 & 6.91 & 1.29 & 0.95 & - & 9.48 & 4.24 & 78.8 & 0.60 & 4.74 \\
\hline 4.6 & 2.11 & 0.40 & 7.59 & 1.34 & 0.97 & - & 10.29 & & & & 5.15 \\
\hline 4.6 & 1.85 & 0.38 & 7.37 & 1.34 & 0.96 & - & 10.05 & & & & 5.03 \\
\hline 4.5 & 1.75 & 0.38 & 8.16 & 1.47 & 0.96 & - & 12.96 & 6.88 & 65.6 & 0.99 & 6.48 \\
\hline 4.7 & 2.18 & 0.34 & 6.58 & 1.30 & 0.96 & - & 9.19 & & & & 4.60 \\
\hline 4.7 & 2.33 & 0.38 & 6.70 & 1.34 & 0.98 & - & 9.39 & & & & 4.70 \\
\hline 4.7 & 2.4 & 0.38 & 7.02 & 1.40 & 0.77 & - & 9.57 & 6.99 & 65.0 & 0.74 & 4.79 \\
\hline 4.7 & 2.28 & 0.37 & 6.19 & 1.38 & 0.99 & - & 8.93 & & & & 4.47 \\
\hline 4.5 & 4.38 & 0.37 & 9.04 & 2.30 & 0.97 & - & 12.67 & 5.06 & 74.7 & 0.85 & 5.07 \\
\hline 4.6 & 3.46 & 0.41 & 7.51 & 2.59 & 0.99 & - & 11.50 & & & & 4.60 \\
\hline 4.6 & 3.43 & 0.42 & 6.10 & 2.61 & 1.01 & - & 10.15 & & & & 4.06 \\
\hline 4.6 & 2.96 & 0.42 & 5.82 & 2.58 & 1.01 & - & 9.83 & 8.12 & 59.4 & 0.83 & 3.93 \\
\hline 4.6 & 6.04 & 0.43 & 5.99 & 2.54 & 1.02 & - & 9.98 & & & & 3.99 \\
\hline 4.6 & 5.78 & 0.38 & 5.67 & 2.34 & 1.02 & - & 9.41 & & & & 3.76 \\
\hline 4.6 & 5.26 & 0.36 & 5.61 & 2.24 & 1.02 & - & 9.23 & 7.74 & 61.3 & 0.75 & 3.69 \\
\hline 4.7 & 4.28 & 0.37 & 5.50 & 2.12 & 1.02 & - & 9.01 & & & & 3.60 \\
\hline 4.7 & 1.89 & 0.33 & 5.62 & 2.29 & 1.03 & - & 9.28 & & & & 3.71 \\
\hline 4.7 & 1.27 & 0.36 & 5.57 & 2.37 & 1.03 & - & 9.33 & 7.67 & 61.6 & 0.76 & 3.73 \\
\hline 4.7 & 1.40 & 0.25 & 5.22 & 2.53 & 1.05 & - & 9.05 & & & & 3.62 \\
\hline 4.7 & 1.46 & 0.33 & 5.58 & 2.70 & 1.06 & - & 9.67 & 9.79 & 51.0 & 0.95 & 3.87 \\
\hline 4.7 & 0.60 & 0.24 & 6.38 & 2.52 & 1.17 & - & 10.31 & 10.3 & 51.5 & 1.06 & 4.12 \\
\hline
\end{tabular}


Table 2 Continuous acidogenesis of synthetic media using $\mathbf{\gamma}$-alumina-supported anaerobic mixed culture (Continued)

\begin{tabular}{|c|c|c|c|c|c|c|c|c|c|c|c|c|c|c|c|}
\hline \multirow[t]{17}{*}{$\begin{array}{l}\text { Sucrose } \\
\text { and raffinose }\end{array}$} & $\begin{array}{l}17 \mathrm{~g} \\
\text { sucrose + } \\
3 \mathrm{~g} \\
\text { raffinose }\end{array}$ & & & & & & & & & & & & & & \\
\hline & & 0.2 & 38 & 4.7 & 1.07 & - & 5.57 & 2.24 & 1.06 & - & 8.87 & & & & 3.55 \\
\hline & & 0.2 & 39 & 4.7 & 1.29 & - & 6.41 & 2.66 & 1.18 & - & 10.26 & & & & 4.10 \\
\hline & & 0.2 & 40 & 4.7 & 1.09 & 0.18 & 6.36 & 2.62 & 1.18 & - & 10.15 & 11.9 & 40.5 & 1.25 & 4.06 \\
\hline & & 0.2 & 41 & 4.7 & 0.78 & 0.34 & 6.12 & 2.37 & 1.17 & - & 10.00 & & & & 4.00 \\
\hline & & 0.2 & 43 & 4.7 & 0.84 & 0.34 & 5.52 & 2.22 & 1.08 & - & 9.16 & & & & 3.66 \\
\hline & & 0.2 & 45 & 4.8 & 0.74 & 0.34 & 5.21 & 2.03 & - & - & 7.59 & 10.8 & 46.0 & 0.82 & 3.04 \\
\hline & & 0.2 & 46 & 4.7 & 0.78 & 0.33 & 5.32 & 2.07 & - & - & 7.72 & & & & 3.09 \\
\hline & & 0.2 & 47 & 4.6 & 0.54 & 0.31 & 5.35 & 2.05 & - & - & 7.71 & & & & 3.08 \\
\hline & & 0.2 & 48 & 4.7 & 0.83 & 0.25 & 5.39 & 2.05 & - & - & 7.69 & & & & 3.08 \\
\hline & & 0.2 & 50 & 4.7 & 0.41 & 0.28 & 5.05 & 2.08 & - & - & 7.41 & & & & 2.96 \\
\hline & & 0.2 & 51 & 4.7 & 0.83 & 0.33 & 5.13 & 2.13 & - & - & 7.59 & 13.2 & 34.0 & 1.12 & 3.04 \\
\hline & & 0.2 & 52 & 4.6 & 0.45 & 0.79 & 5.10 & 1.97 & - & - & 7.86 & & & & 3.14 \\
\hline & & 0.2 & 53 & 4.7 & 0.48 & 0.35 & 5.34 & 1.97 & - & - & 7.66 & 13.1 & 34.5 & 1.11 & 3.06 \\
\hline & & 0.2 & 54 & 4.7 & 0.19 & 0.31 & 5.45 & 1.99 & - & - & 7.75 & & & & 3.10 \\
\hline & & 0.2 & 55 & 4.7 & 0.22 & 0.38 & 5.48 & 2.04 & - & - & 7.90 & & & & 3.16 \\
\hline & & 0.2 & 56 & 4.8 & 0.32 & 0.35 & 5.13 & 2.00 & - & - & 7.49 & & & & 3.00 \\
\hline
\end{tabular}


Table 3 Continuous acidogenesis of vinasse using $\gamma$-alumina-supported anaerobic mixed culture

\begin{tabular}{|c|c|c|c|c|c|c|c|c|c|c|}
\hline \multicolumn{3}{|l|}{ Influent } & \multicolumn{8}{|c|}{ Effluent } \\
\hline Feed & $\begin{array}{l}\text { Flow rate } \\
\text { (L/day) }\end{array}$ & $\begin{array}{l}\text { Operation } \\
\text { time (days) }\end{array}$ & $\mathrm{pH}$ & $\begin{array}{l}\text { Ethanol } \\
(\mathrm{ml} / \mathrm{L})\end{array}$ & $\begin{array}{l}\text { Acetic } \\
\text { acid (g/L) }\end{array}$ & $\begin{array}{l}\text { Lactic } \\
\text { acid (g/L) }\end{array}$ & $\begin{array}{l}\text { Succinic } \\
\text { acid (g/L) }\end{array}$ & $\begin{array}{l}\text { Butyric } \\
\text { acid (g/L) }\end{array}$ & $\begin{array}{l}\text { Total } \\
\text { VFAs (g/L) }\end{array}$ & $\begin{array}{l}\text { VFA productivity } \\
\text { (g/L/day) }\end{array}$ \\
\hline \multirow[t]{2}{*}{$25 \%$ vinasse (1:5) } & 0.2 & 58 & 5.2 & 0.35 & 0.36 & 6.33 & 1.80 & - & 8.49 & 3.40 \\
\hline & 0.2 & 59 & 5.3 & 1.09 & 0.38 & 6.41 & 1.07 & - & 7.86 & 3.14 \\
\hline \multirow[t]{2}{*}{$50 \%$ vinasse (1:5) } & 0.2 & 60 & 5.4 & 0.49 & 0.28 & 9.28 & 0.61 & - & 10.79 & 4.32 \\
\hline & 0.2 & 61 & 5.4 & 1.96 & 0.31 & 13.09 & - & - & 14.03 & 5.61 \\
\hline $75 \%$ vinasse (1:5) & 0.2 & 64 & 5.5 & 0.70 & 0.31 & 11.72 & - & 0.78 & 12.81 & 5.12 \\
\hline \multirow[t]{10}{*}{ 100\% vinasse (1:5) } & 0.2 & 66 & 5.3 & 0.56 & - & 10.45 & - & 2.36 & 12.81 & 5.12 \\
\hline & 0.2 & 67 & 5.3 & 0.34 & - & 9.33 & - & 8.22 & 17.55 & 7.02 \\
\hline & 0.2 & 68 & 5.2 & 0.22 & - & 8.60 & - & 7.53 & 15.79 & 6.32 \\
\hline & 0.2 & 69 & 5.4 & 0.48 & - & 7.06 & - & 2.36 & 9.42 & 3.77 \\
\hline & 0.2 & 71 & 5.4 & 0.28 & - & 6.73 & 1.56 & 7.78 & 16.07 & 6.43 \\
\hline & 0.2 & 72 & 5.3 & 0.44 & - & 6.81 & - & - & 6.81 & 2.72 \\
\hline & 0.2 & 73 & 5.5 & 0.36 & - & 7.37 & - & - & 7.37 & 2.95 \\
\hline & 0.2 & 76 & 5.4 & 0.76 & - & 6.46 & 4.40 & 2.36 & 13.22 & 5.29 \\
\hline & 0.2 & 78 & 5.3 & 0.84 & - & 7.38 & 4.49 & 2.69 & 14.56 & 5.82 \\
\hline & 0.2 & 80 & 5.5 & 0.61 & - & 6.81 & 4.34 & 3.45 & 14.60 & 5.84 \\
\hline \multirow[t]{11}{*}{$100 \%$ vinasse $(1: 10)$} & 0.2 & 81 & 6.1 & 0.89 & - & 7.66 & 4.60 & 4.10 & 16.36 & 6.54 \\
\hline & 0.2 & 82 & 5.8 & 0.40 & - & 6.98 & 4.47 & 3.50 & 14.95 & 5.98 \\
\hline & 0.2 & 84 & 6.0 & 0.16 & - & 6.93 & 4.52 & 4.02 & 15.47 & 6.19 \\
\hline & 0.2 & 85 & 6.2 & - & - & 5.27 & 4.43 & 4.66 & 14.36 & 5.74 \\
\hline & 0.2 & 86 & 6.3 & 0.17 & - & 4.45 & 4.44 & 5.75 & 14.64 & 5.86 \\
\hline & 0.2 & 88 & 6.3 & 0.24 & - & 2.37 & 4.47 & 7.56 & 14.40 & 5.76 \\
\hline & 0.2 & 89 & 6.4 & - & - & - & 4.44 & 9.85 & 14.29 & 5.72 \\
\hline & 0.2 & 90 & 6.2 & 0.13 & - & - & 4.60 & 12.14 & 16.74 & 6.70 \\
\hline & 0.2 & 91 & 6.5 & - & - & 1.88 & 4.93 & 11.71 & 18.52 & 7.41 \\
\hline & 0.2 & 94 & 6.4 & - & - & 1.91 & 5.17 & 11.86 & 18.94 & 7.58 \\
\hline & 0.2 & 95 & 6.3 & - & - & 2.01 & 5.07 & 12.16 & 19.24 & 7.70 \\
\hline
\end{tabular}

a 1.25-L glass tower reactor. The bioreactor was filled with $700 \mathrm{~g}$ of $\gamma$-alumina pellets and equal volumes of $20 \mathrm{~g} / \mathrm{L}$ sucrose medium, and anaerobic culture was added. The bioreactor was placed in an incubator set at $37^{\circ} \mathrm{C}$, and it was left to ferment for 2 days without feeding in order to achieve cell immobilization. Subsequently, fresh sucrose medium was pumped continuously into the bioreactor using a high-accuracy peristaltic pump, and a steady state was obtained in a few days. The bioreactor was pumped continuously and successively with sucrose, sucrose and raffinose mixture, and vinasse as described previously. Samples were taken at various time intervals and analyzed for volatile fatty acids, ethanol, and residual sugar by GC and HPLC as described below.

\section{Media for continuous acidogenic fermentation}

During the continuous anaerobic fermentation, media of various sugar substrates were used successively. At the beginning, $20 \mathrm{~g} / \mathrm{L}$ sucrose was used for 35 days, then a mixed medium of $17 \mathrm{~g} / \mathrm{L}$ sucrose and $3 \mathrm{~g} / \mathrm{L}$ raffinose was tested for 21 days and then concentrated vinasse (sugar-beet) after dilution with water (1:5 dilution for 15 days and 1:10 dilution for 15 days) was the last medium used. Each medium also contained aqueous $\mathrm{NH}_{3}$ and $50 \% \mathrm{H}_{3} \mathrm{PO}_{4}$ (to achieve a COD:N:P ratio of 100:5:1), $\mathrm{NaHCO}_{3} 4 \mathrm{~g} / \mathrm{L}$, and yeast extract $4 \mathrm{~g} / \mathrm{L}$, with $\mathrm{pH}$ adjustment at 7 [11]. The media were sterilized by autoclaving at $120^{\circ} \mathrm{C}$ for $10 \mathrm{~min}$.

\section{GC analysis for ethanol determination}

Ethanol was determined on a Shimadzu GC-8A system (Shimadzu Corporation, Kyoto, Japan), with a Teknokroma HAYE SEP Q 80/100 column, a C-R6A Chromatopac integrator, a $\mathrm{He}$ as carrier gas $(40 \mathrm{~mL} / \mathrm{min})$, and a FID detector. The injection port and detector temperature was $210^{\circ} \mathrm{C}$. The column temperature was $130^{\circ} \mathrm{C}$. Samples of $2 \mu \mathrm{L}$ were 
injected directly into the column. Determinations were done by means of standard curves.

\section{HPLC analysis for VFA and residual sugar determination}

Residual sugar was determined by high-performance liquid chromatography, using a Shimadzu chromatograph with a Nucleogel Ion 300 OA column, a LC-9A pump, a CTO-10A oven at $30^{\circ} \mathrm{C}$, and a RID-6A refractive index detector. $\mathrm{H}_{2} \mathrm{SO}_{4} 0.008 \mathrm{~N}$ was used as mobile phase with a flow rate of $0.8 \mathrm{~mL} / \mathrm{min}$, and propanol- 1 was used as an internal standard. A volume of $0.25 \mathrm{~mL}$ of the sample and $0.625 \mathrm{~mL}$ of a $1 \%(v / v)$ solution of propanol-1 were diluted to $25 \mathrm{~mL}$. Then, $60 \mu \mathrm{L}$ of the final solution was injected directly to the column. Residual sugar and concentrations were calculated using standard curves.

Volatile fatty acids were determined by high-performance liquid chromatography, using a Jasco chromatograph LC2000 Plus (Jasco Analytical Instruments, Tokyo, Japan) with a Bio-rad Aminex HPX-87H column (7.8 mm ID $\times$ $300 \mathrm{~mm}, 9 \mu \mathrm{m}$ particle size), a PU-2089 plus quaternary gradient pump, a Jasco CO-2060 Plus oven at $50^{\circ} \mathrm{C}$, a MD-2018 plus photodiode array detector operated at $210 \mathrm{~nm}$, and an autosampler AS 2050 plus. $\mathrm{H}_{2} \mathrm{SO}_{4}$ $0.008 \mathrm{~N}$ was used as mobile phase with a flow rate of $0.6 \mathrm{~mL} / \mathrm{min}$. The samples were filtered by a membrane filter of $0.45 \mathrm{~nm}$, and all the data were processed with the ChromNav program.

\section{Abbreviations}

COD: chemical oxygen demand; Raf: raffinose; Suc: sucrose; UASB: upflow anaerobic sludge blanket; VFAs: volatile fatty acids.

\section{Competing interests}

The authors declare that they have no competing interests.

\section{Authors' contributions}

$\mathrm{KL}$ performed the experiments presented herein. PK supervised the experiments, assisted in the experimental design, and drafted the manuscript. NB, SK, and NA are industrial partners who designed the experiment, advised academics, and performed the experiments in the continuous system using vinasse. $A B$ and MK supervised the work, designed the experiments, and drafted the manuscript. AAK conceived of the study, supervised the work, designed the experiments, and finally drafted the manuscript. All authors participated in the evaluation of the data and read and approved the final manuscript.

\section{Acknowledgements}

The research project was co-financed by the European Union (European Regional Development Fund - ERDF) and Greek national funds through the Operational Program 'Competitiveness and Entrepreneurship' of the National Strategic Reference Framework (NSRF) 2007-2013 - National Action 'Cooperation 2011: Partnerships of Production and Research Institutions in Focused Research and Technology Sectors' of the General Secretariat for Research and Technology (Contract Nr. 11SYN-8-839).

\section{Author details}

${ }^{1}$ Food Biotechnology Group, Department of Chemistry, University of Patras, 26500 Patra, Greece. ${ }^{2}$ B.G. Spiliopoulos S.A, 26500 Patra, Greece. ${ }^{3}$ I. Athanasopoulos and Co, 106b Lontou Str, 26224 Patra, Greece.

Received: 27 May 2014 Accepted: 17 April 2015

Published online: 07 May 2015

\section{References}

1. Balat $\mathrm{M}$, Balat $\mathrm{H}$. Recent trends in global production and utilization of bio-ethanol fuel. Appl Energy. 2009;86:2273-82.

2. Goldemberg J, Coelho ST, Guardabassi P. The sustainability of ethanol production from sugarcane. Energy Policy. 2008;36:2086-97.

3. España-Gamboa El, Mijangos-Cortés JO, Hernández-Zárate G, Domínquez Maldonado JA, Alzate-Gaviria LM. Methane production by treating vinasses from hydrous ethanol using a modified UASB reactor. Biotechnol Biofuels. 2012;5:82

4. Wheals AE, Basso LC, Alves DMG, Amorim HV. Fuel ethanol after 25 years. Trends Biotechnol. 1999:17:482-7.

5. Smeets $E$, Junginger M, Faaij A, Walter A, Dolzan P, Turkenburga W. The sustainability of Brazilian ethanol - an assessment of the possibilities of certified production. Biomass Bioenergy. 2008;32:781-813.

6. Navarro AR, Sepúlveda MC, Rubio MC. Bio-concentration of vinasse from the alcoholic fermentation of sugar cane molasses. Waste Manage. 2000;20:581-5.

7. Moura AG, Medeiros JR. Applying consistent technology for fuel ethanol production. Sugar Tech. 2008;10:20-4.

8. Ren NQ, Wang BZ, Huang JC. Ethanol-type fermentation from carbohydrate in high rate acidogenic reactor. Biotechnol Bioeng. 1997;54(5):428-33.

9. Contino F, Foucher F, Mounaim-Rousselle C, Jeanmart H. Combustion characteristics of tricomponent fuel blends of ethyl acetate, ethyl propionate, and ethyl butyrate in homogeneous charge compression ignition ( $\mathrm{HCCl}$ ). Energy Fuel. 2011;25:1497-503.

10. Kana K, Kanellaki M, Papadimitriou A, Psarianos C, Koutinas AA. Immobilization of Saccharomyces cerevisiae on $\gamma$-alumina pellets and its ethanol production in glucose and raisin extract fermentation. J Ferment Bioeng. 1989;68:213-5.

11. Koutinas AA, Toutoutzidakis G, Kana K, Kouinis I. Methane fermentation promoted by gamma-alumina pellets. J Ferment Bioeng. 1991;72:64-7.

12. Kanellaki M, Koutinas AA, Kana K, Nicolopoulou M, Papadimitriou A, Lycourghiotis A. Ethanol production by Saccharomyces cerevisiae promoted by $\gamma$-alumina. Biotechnol Bioeng. 1989;34:121-5.

13. Syngiridis K, Bekatorou A, Kallis M, Kandylis P, Kanellaki M, Koutinas AA. $\gamma$-Alumina as a process advancing tool for a new generation biofuel. Bioresour Technol. 2013;132:45-8.

14. Syngiridis K, Bekatorou A, Kandylis P, Larroche C, Kanellaki M, Koutinas AA. Favouring butyrate production for a new generation biofuel by acidogenic glucose fermentation using cells immobilized on $\gamma$-alumina. Bioresour Technol. 2014;161:118-23.

15. Athanasiadis I, Boskou D, Kanellaki M, Kiosseoglou V, Koutinas AA. Whey liquid waste of the dairy industry as raw material for potable alcohol production by kefir granules. J Agric Food Chem. 2002;50(25):7231-4.

\section{Submit your next manuscript to BioMed Central and take full advantage of:}

- Convenient online submission

- Thorough peer review

- No space constraints or color figure charges

- Immediate publication on acceptance

- Inclusion in PubMed, CAS, Scopus and Google Scholar

- Research which is freely available for redistribution 